\title{
Soil Moisture and Temperature Effects on shrunken2 Sweet Corn Seed Decay and Seedling Blight Caused by Penicillium oxalicum
}

\author{
Nancy W. Callan ${ }^{1}$ and James B. Miller ${ }^{2}$ \\ Western Agricultural Research Center, Montana State University, Corvallis MT 59828 \\ Don E. Mathre ${ }^{3}$ \\ Department of Plant Pathology, Montana State University, Bozeman MT 59717 \\ S. Krishna Mohan ${ }^{3}$ \\ Southwest Idaho Research and Extension Center, University of Idaho, Parma ID 83660
}

Additional index words. Pythium ultimum, seedling emergence, seedling stand establishment, seed disinfestation, sodium hypochlorite, $\mathrm{NaOCl}$

\begin{abstract}
Sweet corn (Zea mays L.) seed is commonly infected or infested with fungi that can impair stand establishment. Among these, Penicillium oxalicum Currie and Thorn is known to cause preemergence damping-off or postemergence seedling blight. Supersweet, or shrunken2 (sh2), sweet corn cultivars are particularly affected by seedborne fungal pathogens, although the effects of seed infection on seedling emergence and stand are variable under field conditions. This study was conducted to examine factors that could influence the impact of $P$. oxalicum on seedling stand, including $P$. oxalicum inoculum density on seed and in soil, soil moisture, soil temperature, and control of seed decay caused by soilborne Pythium ultimum Trow. Seed surface disinfestation usually had no effect on seedling stand under conditions favoring infection by $P$. ultimum. Inoculation of $s h 2$ sweet corn seeds or infestation of soil with conidia of $P$. oxalicum resulted in increasing severity of damping-off and seedling blight as inoculum density increased. In pasteurized soil in the greenhouse, an inoculum density of $1^{2} P$. oxalicum conidia per seed reduced emergence and induced seedling blight. In the field, where $P$. ultimum was also a factor, $10^{6}$ conidia per seed were needed to reduce emergence and 105 conidia per seed to reduce healthy seedling stand. When pythium seed decay was controlled by metalaxyl seed treatment, seedling emergence and healthy seedling stand were both reduced at $1 \times 10^{6} \mathrm{P}$. oxalicum conidia per seed. When sh2 sweet corn seed was inoculated with conidia of $P$. oxalicum and incubated in soil at subgermination moisture contents $(4.2$ to -7.8 MPa) for 2-4 weeks before planting and irrigating, $P$. oxalicum reduced seedling emergence at all soil moisture levels, but caused the greatest amount of injury after planting when seeds were incubated in soil above -5.1 MPa. As soil temperature increased from 9-25C, seedling emergence from seed inoculated with $P$. oxalicum was progressively reduced, with a decrease of nearly $50 \%$ at $25 \mathrm{C}$. Penicillium oxalicum has the greatest potential to reduce seedling stand when infected sweet corn seeds are planted in warm, dry soil, but the effects of this and other seedborne fungal pathogens may be masked under conditions favoring infection by $P$. ultimum.
\end{abstract}

The shrunken2 (sh2) or supersweet cultivars of sweet corn are difficult to establish in the field because of physiological seed weakness and disease. In addition to attack by soilborne pathogens such as Pythium ultimum Trow, sweet corn seed is commonly infected or infested with fungi that can reduce seedling stand, including Penicillium oxalicum Currie and Thorn and Fusarium spp. (Kommedahl and Windels, 1981, 1986; Mohan and Wilson, 1990; Schroeder, 1965; Wilson et al., 1993). Many sh2 sweet corn cultivars with the highest culinary qualities produce low vigor seed that is susceptible to fungal infection (Mohan and Wilson, 1990; Styer and Cantliffe, 1984; Wilson and Mohan, 1991). While supersweet cultivars with greater seedling vigor and fungal resistance are being developed by sweet corn breeders, consumer

Received for publication 28 Nov. 1994. Accepted for publication 10 July 1995, Contribution from Montana Agricultural Experiment Station, Montana State Univ., Bozeman, and published as series J-3020, based on research supported by U.S. Dept. of Agriculture Western Regional IPM special grant 91-34103-6131. We thank L. Welty, Northwest Agricultural Research Center, for his cooperation, and Rogers Seed Co., Boise, Idaho, and Crookham Co., Caldwell, Idaho, for supplying seed. The skillful technical support of K. Phillips and J. Jennings is appreciated. The cost of publishing this paper was defrayed in part by the payment of page charges. Under postal regulations, this paper therefore must be hereby marked advertisement solely to indicate this fact.

'Professor of horticulture.

${ }^{2}$ Research specialist.

${ }^{3}$ Professor of plant pathology. demand ensures that the susceptible cultivars will continue to be grown for some time.

Although sweet corn seed normally carries significant inoculum of both P. oxalicum and Fusarium moniliforme J. Sheldon, the role of $F$. moniliforme as a seedborne pathogen in causing seedling disease is not clear (Anderegg and Guthrie, 1981; Kommedahl and Windels, 1981; Styer and Cantliffe, 1984). Fusarium moniliforme isolates vary in pathogenicity (Bacon et al., 1994), as do sweet corn genotypes in susceptibility (Bacon et al., 1994; Styer and Cantliffe, 1984). Other Fusarium species, such as $F$. graminearum Schwabe (syn. F. roseum 'Graminearum') are more consistently pathogenic although less commonly isolated from seed (Kommedahl and Windels, 1981). Penicillium oxalicum is normally pathogenic, and is the major Penicillium species causing injury to sweet corn. Of 15 Penicillium species tested by Caldwell et al. (1981), only $P$. oxalicum reduced seed germination. Mohan and Wilson (1990), in a survey of 50 random seed lots from the 1988 Idaho sweet corn crop, found P. oxalicum in $100 \%$ of the seed lots, with $5 \%-77 \%$ of the seed infected. Likewise, Halfon-Meiri and Solel (1990) found five sweet corn seed lots to have $P$. oxalicum surface contamination of $71 \%-98 \%$ and internal infection of $7 \%-24 \%$. Penicillium oxalicum is widely distributed in soil and decomposing plant residue (Raper and Thorn, 1949). It enters corn ears late in the growing season, particularly those ears with dry, loose husks or earworm damage (Koehler, 1942). Fungi that infect seed in the 
production field may be further spread during seed processing operations. Pericarp injury was found to be important in reducing emergence from $P$. oxalicum-inoculated seeds (Schroeder. 1965). An eaily damaged pericarp and low seedling vigor may contribute to the extreme susceptibility of $s h 2$ sweet corn cultivars to fungal infection (Styer and Cantliffe, 1984).

Penicillium oxalicum seed infection results in a continuum of disease symptoms ranging from preemergence damping-off to a postemergence seedling blight. Seedling stand is reduced when the germinating embryo is killed or when necrosis is induced in the mesocotyl, scutellum, or hypocotyl, resulting in stunting or death of the seedling (Halfon-Meiri and Solel, 1990; Johann, 1928; Johann et al., 1931). Under conditions favoring seedling growth, or with vigorous cultivars that rapidly produce adventitious roots, the seedling may recover or appear resistant to the effects of the fungus (Schroeder, 1965).

Hoppe ( 1953) described P. oxalic-urn as most pathogenic in warm, dry soils, but the effect of soil temperature on P. oxalicum injury is not clear. Johann (1928) reported that seedling emergence was reduced more at higher than at lower temperatures, while Halfon-Meiri and Solel ( 1990) found greater P. oxalicum damping-off when sh2 sweet corn seeds germinated at low temperatures.

To evaluate the impact of external seedborne pathogens of sh2 sweet corn, we examined the effects of surface disinfestation of seed with sodium hypochlorite $(\mathrm{NaOCl})$ on seedling emergence and growth. To define better the conditions under which $P$. oxalicum is most pathogenic to sweet corn seedlings, we tested the effects of $P$. oxalicum inoculum density, pregermination soil moisture, and soil temperature during germination on sweet corn seedling stand in the greenhouse and field. We also investigated the relationship of seedborne $P$. oxalicum and soilborne $P$. ultimum to seedling emergence and stand.

\section{Materials and Methods}

The experiments described here were conducted with nontreated seed of either a relatively low-vigor sh2 sweet corn cultivar, 'Supersweet Jubilee' (Rogers Seed Co., Boise, Idaho) or two sh2 cultivars of higher vigor, 'Crisp 'N Sweet 710' and 'Crisp ' $\mathrm{N}$ Sweet 711' (Crookham Co., Caldwell, Idaho). Nontreated seed of 'Supersweet Jubilee' was heavily infected and infested with $P$. oxalicum (86\%) and $F$. moniliforme $(98 \%)$, while surface disinfestation reduced $P$. oxalicum to $15 \%$ and $F$. moniliforme to $50 \%$. Seed of 'Crisp 'N Sweet 710' was also heavily infected with $P$. oxalicum (99\%) and $F$. moniliforme (82\%), with surfacedisinfested seed. carrying $11 \%$ P. oxalicum and an undetermined level of $F$. moniliforme.

\section{Surface disinfestation of seed}

We conducted a preliminary experiment in which both surfacedisinfested and nontreated seeds were planted in pasteurized soil from the Western Agricultural Research Center (WARC), Corvallis, Mont., a Burnt Fork Sandy Loam, pH 7.4, and in WARC soil naturally infested with $P$. ultimum, the major cause of seed decay in this soil (Callan et al., 1990). Seeds of 'Supersweet Jubilee' were disinfested in $0.4 \% \mathrm{NaOCl}$ plus Tween-20 (1 drop/100 ml) for 5 rein, rinsed for $5 \mathrm{~min}$ in running tap water, and air-dried before planting. To reduce $P$. ultimum inoculum density, natural soil with 167 ppg (germinable propagules per gram) P. ultimum was diluted 1:19 with pasteurized soil. Six replications of 36 seeds each were planted in 72-cell plug flats in the greenhouse. Treatment of nondisinfested seeds with the systemic fungicides metalaxyl (Apron 25W, Ciba-Geigy Co., $0.3 \mathrm{~g}$ a.i./kg) or imazalil (Flo Pro IMZ
32 FL, Gustafson Co., $0.1 \mathrm{~g}$ a.i./kg) and a bio-priming seed treatment, which involved disinfestation and inoculation with Pseudomonas aureofaciens AB254 (Callan et al., 1990, 1991; Mathre et al., 1994), aided in defining disease impacts. Metalaxyl is a selective fungicide that is effective against Pythium spp. and other oomycetous fungi. Imazalil has a spectrum of activity that includes $P$. oxalicum on sweet corn (Halfon-Meiri and Solel, 1989), fusarium root rot of spring wheat (Johnston and Mathre, 1993), and Penicillium spp. dry seed decay of winter wheat (Mathre and Johnston, 199 1).

For comparison with the greenhouse test, seedling emergence from six field experiments in three locations over 2 years are presented. Experiments were conducted in a soil with moderate to high levels of P. ultimum (WARC), a soil with nondetectable to very low levels of $P$. ultimum (Creston Silt Loam, Northwestern Agricultural Research Center, Creston, Mont.), and a soil with low P. ultimum (Green Leaf Owyhee Silt Loam, Univ. of Idaho Southwest Research and Extension Center, Parma). Six replications of 50 'Supersweet Jubilee' seeds each were planted in single rows $2.5 \mathrm{~m}$ long, with seeds $5 \mathrm{~cm}$ apart and $3.5 \mathrm{~cm}$ deep. Planting was done by hand in the Montana locations and with a cone seeder in Parma. Plots were preirrigated or irrigated immediately after planting. Soil temperatures at $10.2 \mathrm{~cm}$ were obtained from $\mathrm{Na}-$ tional Oceanic and Atmospheric Service installations at each location. Pythium ultimum propagule density was determined at the beginning of each experiment using the procedures of AliShtayeh et al. ( 1986). Seedlings were counted after full emergence. In some experiments, each seedling was measured to the tip of the longest leaf after emergence but before competition between seedlings occurred. In others, vigorous seedling stand, which combines seedling emergence and vigor, was determined. The mean height of seedlings of a control treatment, normally imazalil plus metalaxyl, was rounded to the nearest $5 \mathrm{~cm}$, and the number of seedlings equal to or exceeding this height were counted. Vigorous seedling stand was expressed as a percentage of the number of seeds planted.

\section{Penicillium oxalicum inoculum density}

Seed inoculation. To determine the effect of inoculum density on sweet corn seedling emergence and growth, seeds were treated with conidia of $P$. oxalicum isolate P3 (isolated by S. K. Mohan) or isolate \#7 (isolated by N. Callan) from sweet corn seed. Cultures were grown for 2 weeks on potato-dextrose agar (PDA) at 20C. Spores were scraped from the medium with $20 \mathrm{ml}$ of sterile water and 1 drop of Tween-20, filtered through cheesecloth, and the spore density determined using a hemacytometer. Two hundred seeds of 'Crisp 'N Sweet 710' were surface-disinfested with $0.4 \%$ $\mathrm{NaOCl}$ as above and the seed allowed to imbibe $6.6 \mathrm{ml}$ of the spore suspension adjusted to provide 102 to $10 \mathrm{~b}$ conidia of $P$. oxalicum per seed. The seeds were air-dried at room temperature overnight before planting in untreated soilless potting mix (Sunshine \#3; Fisons, Vancouver, B. C.) in 72-cell plug flats in the greenhouse. Thirty-six seeds were planted for each of five replications. Dilution plating was performed at the time of planting to verify the $P$. oxalicum inoculum density on the seed. Three replications of five seeds each were soaked in phosphate buffer for $30 \mathrm{~min}$ with vortex agitation at 10 -min intervals and $0.1 \mathrm{ml}$ plated on PDA with 100 mg.liter ${ }^{-1}$ streptomycin (PDAS). In addition to seeds treated with the two Penicillium isolates, surface-disinfested and imazaliltreated seeds were included.

The above greenhouse experiment was repeated in the field at WARC. 'Crisp 'N Sweet 711' seed was coated with conidia of $P$. oxalicum $\mathrm{P} 3$ as described above. All seeds except nontreated were 
first disinfested. For each $P$. oxalicum inoculum density, an additional treatment including metalaxyl was added to minimize the effects of $P$. ultimum on seedling emergence and growth. The experiment was planted on 10 June 1992 in soil naturally infested with $183 \mathrm{ppg} P$. ultimum. Five replications of 50 seeds per $2.5 \mathrm{~m}$ plot were hand planted $5 \mathrm{~cm}$ apart and $3.5 \mathrm{~cm}$ deep. Seedlings were counted at full emergence and each seedling was measured to the tip of the longest leaf on 10 July 1992.

Soil infestation. Because $P$. oxalicum is a common soil saprophyte (Raper and Thorn, 1949), we wished to compare the effects of soil infestation to seed inoculation on seedling emergence and stand. Infestation of sterile soil usually leads to abnormally high disease pressure, so we used a natural soil with low levels of soilborne pathogens. WARC soil from a site that had not been cultivated for at least 30 years, with $P$. ultimum less than 7 ppg, was infested with conidia of $P$. oxalicum P3 to yield the desired inoculum density. Levels of $P$. oxalicum were confirmed by dilution plating on PDAS. In the first experiment, $0,7 \times 10^{3}, 7$ $\mathrm{x} 10^{4}$, and $7 \times 10^{5}$ conidia per gram of dry soil were used. In the second, inoculum was adjusted to eight increments from 0 to $10^{6}$ conidia per gram. Plug flats (72-cell) were filled with soil and surface-disinfested seeds of 'Crisp ' $N$ Sweet 710' planted in four replications of 36 seeds per replication. Flats were placed in the WARC growth room at 20-23C and emerged seedlings counted after 2 weeks. After 3 weeks, seedlings were classified as healthy if they had normal color and a visible second leaf, considered to be evidence of an active growing point.

\section{Pregermination soil water potential}

Experiments were conducted to determine whether $P$. oxalicum would grow and sporulate on sh2 sweet corn seed under subgermination soil moisture conditions, and whether incubation of inoculated seeds in soil too dry to support seed germination would result in disease. In preliminary experiments, no seed germination occurred in soil drier than 4.0 MPa while seed at $-3.4 \mathrm{MPa}$ germinated fully. Therefore, to prevent germination, all experiments were conducted using soil at less than 4.0 MPa water potential.

Twenty-four surface-disinfested seeds of 'Crisp 'N Sweet 710' sweet corn, either noninoculated or inoculated with $2 \times 10^{3}$ conidia of $P$. oxalicum P3 per seed, were placed in each of six $15-\mathrm{cm}-$ diameter Petri dishes containing $215 \mathrm{~g}$ of pasteurized WARC soil. The soil was adjusted gravimetrically to eight levels between -7.8

Table 1. Crisp 'N Sweet710 sh2 sweet corn seedling emergence in Pythium ultimuminfested soil in the greenhouse as affected by seed treatment.

\begin{tabular}{llc}
\hline \hline $\begin{array}{l}\text { Seed } \\
\text { treatment }\end{array}$ & \multicolumn{1}{c}{$\begin{array}{c}\text { Seed treatment } \\
\text { specifications } \\
\text { (rate/timing) }\end{array}$} & $\begin{array}{c}\text { Seedling } \\
\text { emergence (\%) }\end{array}$ \\
\hline Nontreated & $\begin{array}{c}\text { Pasteurized soil } \\
\text { None }\end{array}$ & $76 \mathrm{bc}^{2}$ \\
Surface-disinfested & $0.4 \% \mathrm{NaOCl}, 5 \mathrm{~min}$ & $85 \mathrm{~d}$ \\
Imazalil & $0.1 \mathrm{~g}$ a.i./kg & $84 \mathrm{~cd}$ \\
& Nonpasteurized soil & $35 \mathrm{a}$ \\
Nontreated & None & $35 \mathrm{a}$ \\
Surface-disinfested & $0.4 \%$ NaOCl, 5 min & $37 \mathrm{a}$ \\
Imazalil & $0.1 \mathrm{~g}$ a.i./kg & $82 \mathrm{bcd}$ \\
Metalaxyl & $0.3 \mathrm{~g}$ a.i./kg & $90 \mathrm{~d}$ \\
Imazalil plus metalaxyl & $0.1 / 0.3 \mathrm{~g}$ a.i./kg & $82 \mathrm{bcd}$ \\
Bio-primed with Pseudomonas & &
\end{tabular}

${ }^{\overline{ }}$ Mean separation within columns by protected LSD, $P=0.05$.

yseudomonas aureofaciens AB254 at planting: $1.5 \times 108 \mathrm{cfu} / \mathrm{seed}$. and $-4.2 \mathrm{MPa}$, based on a moisture release curve. The dishes were sealed with parafilm and incubated at 20-22C, after which the seeds were screened from the soil. Seeds were then planted in a soilless planting mix (Sunshine \#3), watered well, and healthy (symptomless) seedlings were counted after 2 weeks. The experiment was conducted twice, with either a 2- or 4-week preplant incubation period.

A fall field experiment was conducted at WARC in relatively dry soil to reduce the impact of $P$. ultimum on seedling stand and vigor. Seeds were hand planted in six replications of $2.5-\mathrm{m}$ singlerow plots, with 50 seeds per plot planted $5 \mathrm{~cm}$ apart and $3.5 \mathrm{~cm}$ deep. Irrigation was delayed 5 days after planting. Seedlings were counted at full emergence, and each seedling was measured to the tip of the longest leaf 22 days after planting.

\section{Soil temperature}

A thermal gradient table was used to control soil temperature. The table was constructed from twelve $1.8 \mathrm{~m} \mathrm{x} 15 \mathrm{~cm}$ aluminum bars, along the length of which a controlled temperature gradient was established by circulating heated water through one end of the table and chilled water through the opposite end. Petri dishes (15$\mathrm{cm}$-diameter) filled with soil at $-0.03 \mathrm{MPa}$ were spaced equidistantly on the aluminum bars, and the bar temperature was monitored with a thermocouple. Strips of foil-covered structural foam (Firestone Building Products Co., Salt Lake City) were placed between the dishes perpendicular to the gradient, and the entire table was covered with sheets of foam to increase temperature uniformity.

To determine the effects of soil temperature on seedling disease caused by $P$. oxalicum, seeds of 'Crisp 'N Sweet 710' sh2 sweet corn were disinfested with $\mathrm{NaOCl}$ as above and either planted without further treatment or inoculated with $2 \times 10^{3}$ conidia of P. oxalicum P3 per seed. Inoculum density of $P$. oxalicum was confirmed by dilution plating on PDAS. The experiment was conducted twice with modifications. Seeds were planted in pasteurized WARC soil in four replications of 25 or 15 seeds per petridish for the first and second experiments, respectively. A temperature gradient of 9 to $24 \mathrm{C}$ was maintained for 4 or 7 days, respectively, after which the table was allowed to come to equilibrium with room temperature (20C) for seedling emergence. Seedlings were counted at full emergence, after which the endosperm and pericarp remnants were examined for visible sporulation of Penicillium spp.

Plot design and data analysis. All experiments were conducted using a randomized complete block design. Data were analyzed using the analysis of variance, general linear model, or regression modules of MSUSTAT (Lund, 1994). All percentage data were transformed to the arcsin of the square root of the proportion before analysis. Mean separation was by protected LSD, 5\% level. Penicillium Oxalicum inoculum density was log transformed (base 10) before analysis.

\section{Results and Discussion}

\section{Surface disinfestation}

In pasteurized soil in the greenhouse, surface disinfestation with $\mathrm{NaOCl}$ increased seedling emergence slightly over that from nontreated seed of Crisp 'N Sweet 710' (Table 1 ). In natural P. ultimuminfested soil, this effect was masked by pythium seed decay, as demonstrated by increased seedling emergence after metalaxyl seed treatment or bio- 
Table 2. Supersweet Jubilee seedling emergence as affected by seed treatment in a field experiment at the Western Agricultural Research Center (WARC), Corvallis, Mont. and at the Southwest Idaho Research and Extension Center (SIREC), Parma, Idaho. ${ }^{2}$

\begin{tabular}{|c|c|c|c|}
\hline Seed & $\begin{array}{l}\text { Seed treatment } \\
\text { specifications }\end{array}$ & \multicolumn{2}{|c|}{$\begin{array}{c}\text { Seedling } \\
\text { emergence }(\%)\end{array}$} \\
\hline treatment & (rate/timing) & \multicolumn{2}{|c|}{ WARC SIREC } \\
\hline Nontreated & None & $20 a^{y}$ & $33 a b$ \\
\hline Surface-disinfested & $0.4 \% \mathrm{NaOCl}, 5 \mathrm{~min}$ & $20 \mathrm{a}$ & $32 \mathrm{a}$ \\
\hline Imazalil & $0.1 \mathrm{~g}$ a.i. $/ \mathrm{kg}$ & $30 \mathrm{a}$ & $46 \mathrm{bc}$ \\
\hline Metalaxyl & $0.3 \mathrm{~g}$ a.i. $/ \mathrm{kg}$ & $51 \mathrm{~b}$ & $30 \mathrm{a}$ \\
\hline Imazalil plus metalaxyl & $0.1 / 0.3 \mathrm{~g}$ a.i. $/ \mathrm{kg}$ & $71 \mathrm{c}$ & $53 \mathrm{c}$ \\
\hline $\begin{array}{l}\text { Bio-primed with Pseudomonas } \\
\text { aureofaciens AB } 254\end{array}$ & Bio-primed $20 \mathrm{~h}$ at $23 \mathrm{C}^{\mathrm{x}}$ & $72 \mathrm{c}$ & $52 \mathrm{c}$ \\
\hline
\end{tabular}

${ }^{\overline{2}}$ Planted 12 Sept. 1991 (WARC) and 28 Apr. 1992 (SIREC). Average soil temperatures during the 3 days after planting: (max/min) 23.0/17.8C (WARC) and 22.8/15.4 C (SIREC). Pythium ultimum in soil: $333 \mathrm{ppg}$ (WARC) and $25 \mathrm{ppg}$ (SIREC).

${ }^{y}$ Mean separation within columns by protected LSD, $P=0.05$.

${ }^{x}$ Pseudomonas aureofaciens AB254 at planting: 5.4 x $107 \mathrm{cfu} / \mathrm{seed}$ (WARC), $5.5 \times 10^{8} \mathrm{cfu} /$ seed (SIREC).

priming with $P$. aureofaciens $\mathrm{AB} 254$.

A field experiment conducted at WARC in 1991 (Table 2) demonstrated a pattern of seedling emergence similar to that seen in the above greenhouse experiment. Pythium seed decay was severe, and emergence was not increased by either surface disin festation or treatment with imazalil alone. However, when $P$. ultimum was controlled by metalaxyl, addition of imazalil increased seedling emergence further. Bio-priming with $P$. aureofaciens AB254 also increased emergence. In Parma (Table 2 ), based on a comparison of the effectiveness of the fungicides metalaxyl and imazalil, it appeared that pathogens other than Pythium spp. were responsible for reducing seedling emergence. Seed disinfestation had no effect on emergence. Fungicide seed treatment combinations containing thiabendazole or thiram were more effective than imazalil plus metalaxyl in increasing seedling emergence in this experiment (data not shown).

Field experiments conducted in 1992 and 1993 demonstrated the influence of environmental conditions on the relative importance of P. ultimum and soil- and seedborne pathogens. In 1992, a season of low precipitation and temperatures favorable for plant growth in western Montana, an increase in seedling stand due to surface disinfestation of seed was observed at both WARC and NWARC (Table 3). At WARC, fungicide treatments also increased seedling stand, with imazalil more effective than metalaxyl. This indicates that pythium seed decay was less of a factor than were seedborne and soilborne fungi that were controlled by imazalil, although addition of metalaxyl to the imazalil treatment increased stand further. Average seedling height was increased only by the combination of fungicides, but the stand of seedlings over 15 $\mathrm{cm}$ was also increased by imazalil treatment alone. At NWARC, there was little evidence of pythium seed decay, and a response to both disinfestation and imazalil treatment was seen. Despite a lack of response to metalaxyl alone, addition of metalaxyl to the imazalil treatment further increased seedling stand.

In contrast, in 1993, a growing season of abovenormal precipitation and below-normal temperatures, pythium seed decay was a significant cause of stand reduction in both locations, as shown by the magnitude of response to metalaxyl seed treatment (Table 4). At WARC, with higher soil populations of $P$. ultimum, disinfestation had no effect on either seedling emergence or vigor. At NWARC, cold, wet soils were conducive to seed decay despite the low $P$. ultimum levels in the soil. No increase in seedling emergence due to surface disinfestation was seen at NWARC, but the stand of vigorous seedlings was increased when disinfestation was used alone or combined with fungicide treatments controlling $P$. ultimum, i.e., metalaxyl or metalaxyl plus imazalil. Surface disinfestation decreased seedling emergence when combined with the fungicide imazalil, but had no effect on vigorous plant stand. These experiments demonstrate the ability of $P$. ultimum to mask the effects of seedborne and undoubtedly other soilborne fungi. Pythium ultimum rapidly decays sweet corn seeds, often before they germinate, and under high disease pressure appears to do so regardless of the presence of external seedborne pathogens. However, when Pythium disease pressure is low, seedborne pathogens may exert a greater effect on seedling emergence and, perhaps more frequently, seedling vigor.

Increases in $s h 2$ sweet corn seed germination in the laboratory have been achieved through surface disinfestation of seed, but effects on seedling emergence in the field have been variable. Parera and Cantliffe(1991 ) found that standard laboratory germination of the low-vigor sh 2 sweet corn cultivar 'How Sweet It Is' was improved by surface disinfestation with $\mathrm{NaOCl}$, but that of the more vigorous sh2 cultivar 'Crisp 'N Sweet 711' was not. Seed germination in the cold test was reduced by $\mathrm{NaOCl}$ treatment

Table 3. Supersweet Jubilee seedling emergence, average plant height, and vigorous seedling stand in the field as affected by seed treatment at the Western Agricultural Research Center, Corvallis, Mont. (WARC) and the Northwestern Agricultural Research Center, Creston, Mont. (NWARC).

\begin{tabular}{|c|c|c|c|c|c|c|}
\hline \multirow[b]{2}{*}{$\begin{array}{l}\text { Seed } \\
\text { treatment }\end{array}$} & \multicolumn{3}{|c|}{ WARC } & \multicolumn{3}{|c|}{ NWARC } \\
\hline & $\begin{array}{l}\text { Stand } \\
(\%)\end{array}$ & $\begin{array}{l}\text { Height } \\
(\mathrm{cm})\end{array}$ & $\begin{array}{c}\text { Stand over } 15 \mathrm{~cm} \\
(\%)^{y}\end{array}$ & $\begin{array}{l}\text { Stand } \\
(\%)\end{array}$ & $\begin{array}{l}\mathrm{Ht} \\
(\mathrm{cm})\end{array}$ & $\begin{array}{c}\text { Stand over } 10 \mathrm{~cm} \\
(\%)\end{array}$ \\
\hline Nontreated & $30 a^{x}$ & $14.5 \mathrm{a}$ & $14 \mathrm{a}$ & $28 \mathrm{a}$ & $10.5 \mathrm{a}$ & $16 a$ \\
\hline Disinfested & $45 \mathrm{~b}$ & $14.4 \mathrm{a}$ & $22 \mathrm{ab}$ & $57 \mathrm{~b}$ & $12.5 \mathrm{~b}$ & $40 \mathrm{~b}$ \\
\hline lmazalil & $62 \mathrm{c}$ & $15.1 \mathrm{ab}$ & $31 \mathrm{~b}$ & $67 \mathrm{c}$ & $12.6 \mathrm{~b}$ & $52 \mathrm{c}$ \\
\hline Metalaxyl & $52 \mathrm{~b}$ & $14.3 \mathrm{a}$ & $24 \mathrm{ab}$ & $29 a$ & $10.5 \mathrm{a}$ & $16 \mathrm{a}$ \\
\hline Imazalil plus metalaxyl & $76 \mathrm{~d}$ & $16.4 \mathrm{~b}$ & $44 \mathrm{c}$ & $77 \mathrm{~d}$ & $13.6 \mathrm{~b}$ & $60 \mathrm{c}$ \\
\hline
\end{tabular}

Planted 15 May 1992 (WARC) and 3 June 1992 (NWARC). The average soil temperature for the 3 days following planting : (max/min) 23.3/18.9C (WARC) and 15.6/1 5.0 C (NWARC). Pythium ultimum in soil :300 ppg (WARC) and 50 ppg (NWARC).

${ }^{y}$ Seedling stand and stand over 10 or $15 \mathrm{~cm}$ expressed as a percentage of seeds planted. Seedling height measured 16 June 1992 (WARC), and 1 July 1992 (NWARC).

${ }^{\times}$Mean separation within columns by protected LSD, $P=0.05$. 
(Parera and Cantliffe, 1992). Seedling emergerice of $s h 2$ sweet corn in the field was not improved by seed disinfestation with $\mathrm{NaOCl}$, although the combination of disinfestation and solid matrix priming increased emergence and was considered to be a promising alternative to chemical fungicide treatment (Parera and Cantliffe, 1992, 1994). The effect of seed disinfestation on sh2 sweet corn seedling emergence and vigor appears to depend on the sweet corn cultivar, the disinfestation method, the degree of fungal infestation of the seed, and the conditions under which germination takes place, including disease pressure from soilborne pathogens such as $P$. ultimum.

\section{Penicillium oxalicum inoculum density}

Seed inoculation. In the greenhouse, $P$. oxalicum isolates P3 and \#7 were highly pathogenic to sweet corn (Table 5). Penicillium oxalicum injury is normally exhibited as both a reduction in emergence and a necrosis or stunting of a portion of the seedlings. Inoculum densities as low as 102 conidia per seed of P. oxalicum P3 or $10^{3}$ conidia per seed of isolate \#7 were sufficient to reduce both seedling emergence and the final stand of symptomless plants when compared to either the disinfested control or imazalil treatment. As inoculum density increased, seedling emergence and stand were reduced. Sporulation of Penicillium spp. was observed on remnants of nongerminated seeds and blighted seedlings from inoculated seed, and Penicillium spp. could be isolated from tissues adjacent to lesions. Halfon-Meiri and Solel (1990) also found increasing severity of seedling blight as inoculum applied to seeds planted in sand increased from $3 \times 10^{3}$ to $3 \times 105$ conidia per seed. According to Johann et al. (1931), P. oxalicum is unable to enter unwounded cells but produces oxalic acid, which injures tissues in advance of mycelial penetration and aids it in parasitic growth. Seedling blight was more severe under conditions of abundant nutrient supply and high inoculum levels, which promoted oxalic acid production (Johann et al., 1931).

The low P. oxalicum inoculum densities that were sufficient for stand reduction in sterile or pasteurized media are in contrast to the relatively high levels needed to cause disease in the field (Fig. 1). A higher inoculum density was required to reduce seedling emergence than vigorous seedling stand. With or without control of Pythium seed decay by metalaxyl treatment, $10^{6}$ conidia of $P$. oxalicum per seed was required to reduce seedling emergence when compared to the metalaxyl or surface-disinfested seed treatments, respectively. With metalaxyl treatment, $10^{6} \mathrm{P}$. oxalicum conidia per seed were required to reduce the stand of seedlings over $15 \mathrm{~cm}$ tall at 4 weeks after planting when compared to that resulting from metalaxyl treatment alone, but without metalaxyl treatment, only $10^{5}$ conidia of $P$. oxalicum per seed reduced vigorous seedling stand when compared to that from surface-disinfested seed. Seedling emergence and vigorous seedling stand were improved by metalaxyl and metalaxyl plus imazalil treatment, while imazalil and surface disinfestation alone had no effect.

\section{Soil infestation}

Infestation of nonpasteurized soil with conidia of $P$. oxalicum resulted in seed decay and seedling blight, but at relatively high inoculum levels. As with seed inoculation, more inoculum was required to reduce seedling emergence than to reduce vigorous seedling stand. In the first experiment, soil infestation of $0,7 \times 10^{3}$, $7 \times 10^{4}$, and $7 \times 10^{5}$ conidia per gram of soil resulted in $89 \%$ a, $92 \%$ a, $89 \%$ a, and $76 \%$ b seedling emergence, with $86 \%$ a, $85 \%$ a, $69 \%$ b, and $33 \%$ c symptomless seedling stand, respectively (LsD, $P=$ 0.05). Similarly, in the second experiment (Fig. 2), $5 \times 10^{5}$ conidia per gram of soil were required to reduce seedling emergence, but 104 conidia were sufficient to reduce the stand of healthy seedlings when compared to those grown in noninfested soil. A piecewise fitted regression was used for the data presented in Fig. 2, as no effect of increasing inoculum density was seen below $10^{3}$ conidia/ seed. While no data regarding normal levels of $P$. oxalicum in soil have been published, Penicillium citrinum Thom was reported at $2 \times 10^{4}$ conidia per gram of soil (Chuang and Ko, 1981). At a

Table 5. Seedling emergence and seedling stand of Crisp ' $N$ Sweet $710 s h 2$ sweet corn following surface disinfestation with $\mathrm{NaOCl}$ and inoculation with Penicillium oxalicum isolate P3 or \#7, or treatment with imazalil.

\begin{tabular}{lcc}
\hline \hline Seed treatment & Maximum emergence $(\%)^{y}$ & Final stand $(\%)^{\mathrm{x}}$ \\
\hline P. oxalicum P3 & $68 \mathrm{ef}^{v}$ & $18 \mathrm{e}$ \\
$10^{2 \mathrm{w}}$ & $59 \mathrm{de}$ & $9 \mathrm{cde}$ \\
$10^{3}$ & $36 \mathrm{c}$ & $2 \mathrm{abc}$ \\
$10^{4}$ & $16 \mathrm{~b}$ & $2 \mathrm{ab}$ \\
$10^{5}$ & $9 \mathrm{ab}$ & $2 \mathrm{ab}$ \\
$10^{6}$ & & \\
$P$. oxalicum $\# 7$ & $76 \mathrm{fg}$ & $36 \mathrm{f}$ \\
$10^{2}$ & $67 \mathrm{ef}$ & $13 \mathrm{de}$ \\
$10^{3}$ & $46 \mathrm{~cd}$ & $5 \mathrm{bcd}$ \\
$10^{4}$ & $20 \mathrm{~b}$ & $1 \mathrm{ab}$ \\
$10^{5}$ & $5 \mathrm{a}$ & $0 \mathrm{a}$ \\
$10^{6}$ & $83 \mathrm{~g}$ & $72 \mathrm{~g}$ \\
Surface-disinfested & $79 \mathrm{~g}$ & $76 \mathrm{~g}$ \\
Imazalil & & \\
\hline
\end{tabular}

${ }^{\overline{2}}$ Planted in soilless potting mix (Sunshine \#3), WARC greenhouse, 19 Dec. 1990

${ }^{y}$ Stand 12 days after planting.

${ }^{\mathrm{x}}$ Stand 40 days after planting.

${ }^{\mathrm{w}}$ Conidia applied per seed.

"Mean separation within columns by protected LSD, $P=0.05$. 


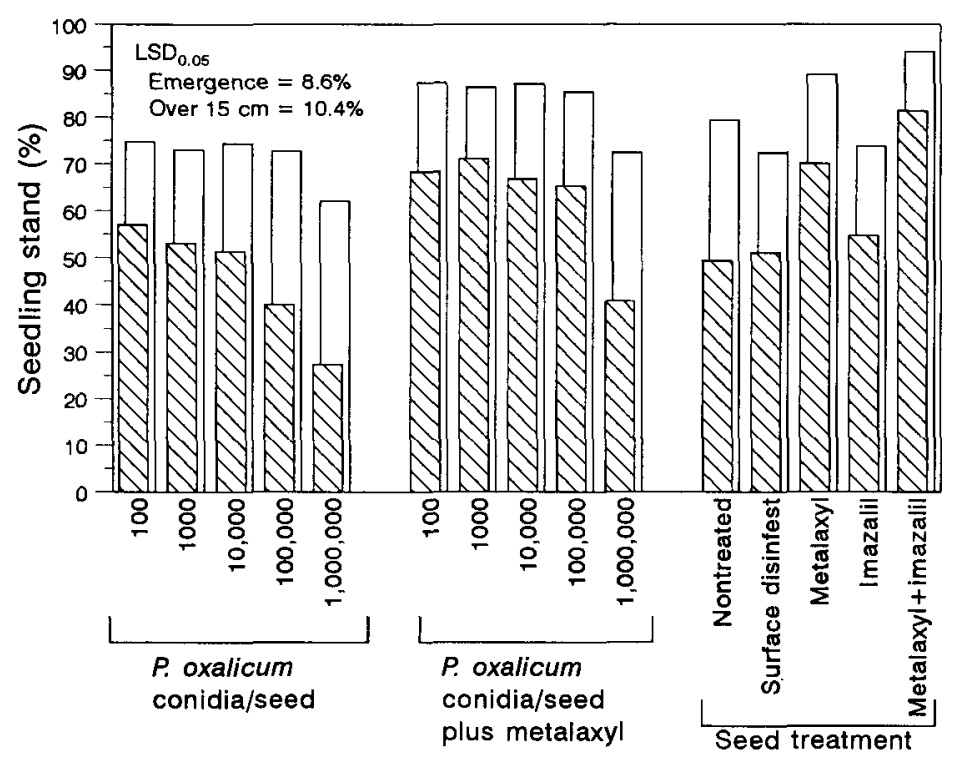

$\triangle$ Plants over $15 \mathrm{~cm} \square$ All emerged seedlings

Fig. 1. Seedling emergence and stand of 'Crisp 'N Sweet 710' sh2 sweet corn in the field after disinfestation with $0.4 \% \mathrm{NaOCl}$ or treatment with metdaxyl $(0.3 \mathrm{~g}$ a.i./ $\mathrm{kg})$ or imazalil $(0.1 \mathrm{~g} \mathrm{a} . \mathrm{i} / \mathrm{kg})$ and inoculation with conidia of Penicillium oxalicum.

comparable inoculum den sit y of P. oxalicum, soilborne as well as seedborne inoculum could be involved in seedling disease. However, we feel that seedborne inoculum of $P$. oxalicum is responsible for the greatest proportion of sweet corn seedling injury.

\section{Pregermination soil water potential}

Seed germination was inhibited at all pregermination water potentials due to lack of available moisture. Seedling emergence and healthy seedling stand from disinfested, noninoctdated seed were reduced after a 2 -week incubation in soil above -5 . $1 \mathrm{MPa}$ (Fig. 3A). Seedborne fungi, including P. oxalicum, that are not

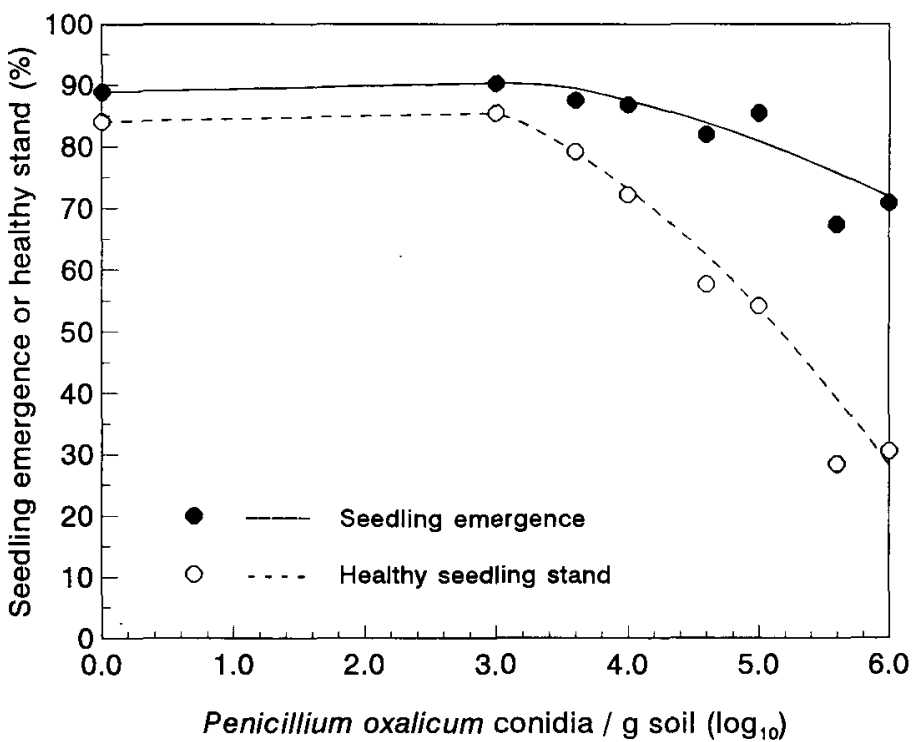

Fig. 2. Seedling emergence and healthy plant stand of 'Crisp 'N Sweet 710' sh2 sweet corn from nonpasteurized soil infested with conidia of Penicillium oxalicum $\mathrm{Y}($ emergence $)=89.89+4.24 \mathrm{X}-1.21 \mathrm{X}^{2}, \mathrm{r}^{2}=0.660^{* *}$. $\mathrm{Y}($ healthy stand $)=85.48$ $+9.84 \mathrm{X}-3.23 \mathrm{X}^{2}, \mathrm{r}^{2}=0.933 * *$.

eliminated by disinfestation could have contributed to this reduction, as could physiological damage to the seed at a soil relative humidity of $96 \%$ and above (Papendick and Campbell, 1981). Seedling emergence and healthy seedling stand were reduced by inoculation with $P$. oxalicum at all pregermination soil moisture levels (Fig. 3B), but were reduced to the greatest extent above -5.1 MPa. Many seedlings from P. oxalicum- treated seed were severely stunted and displayed symptoms of seedling blight. Soil moisture effects on seedling emergence and healthy seedling stand were similar after 4 weeks of preplant incubation.

In a fall planting with a 5-day delay in irrigation, the impact of P. ultimum on seedling stand was reduced but still evident (Table

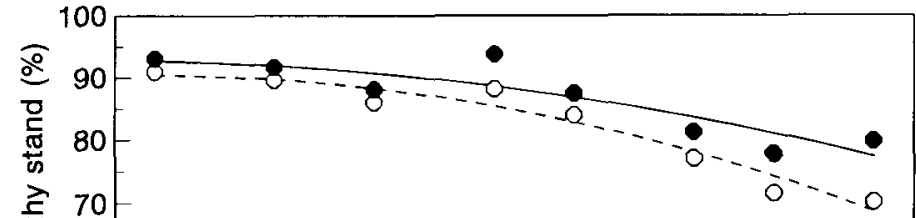

A. Seed disinfested only

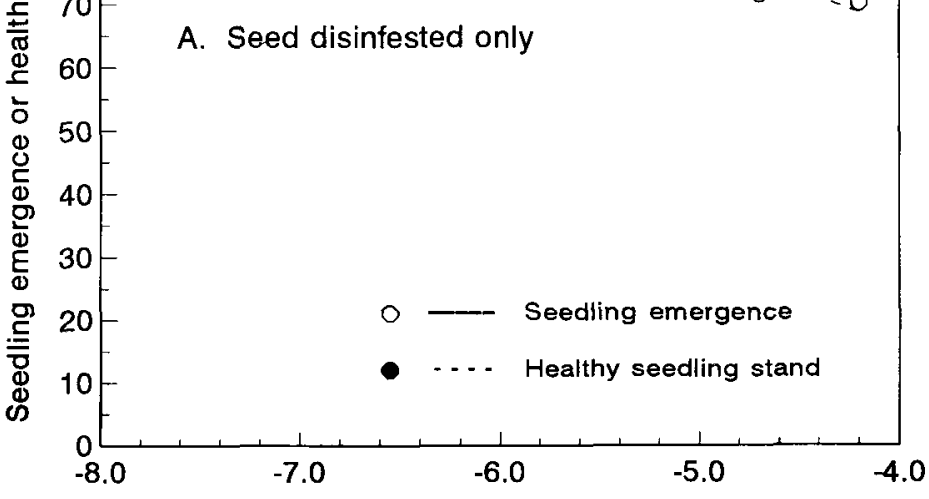

Preplant incubation soil water potential (MPa)

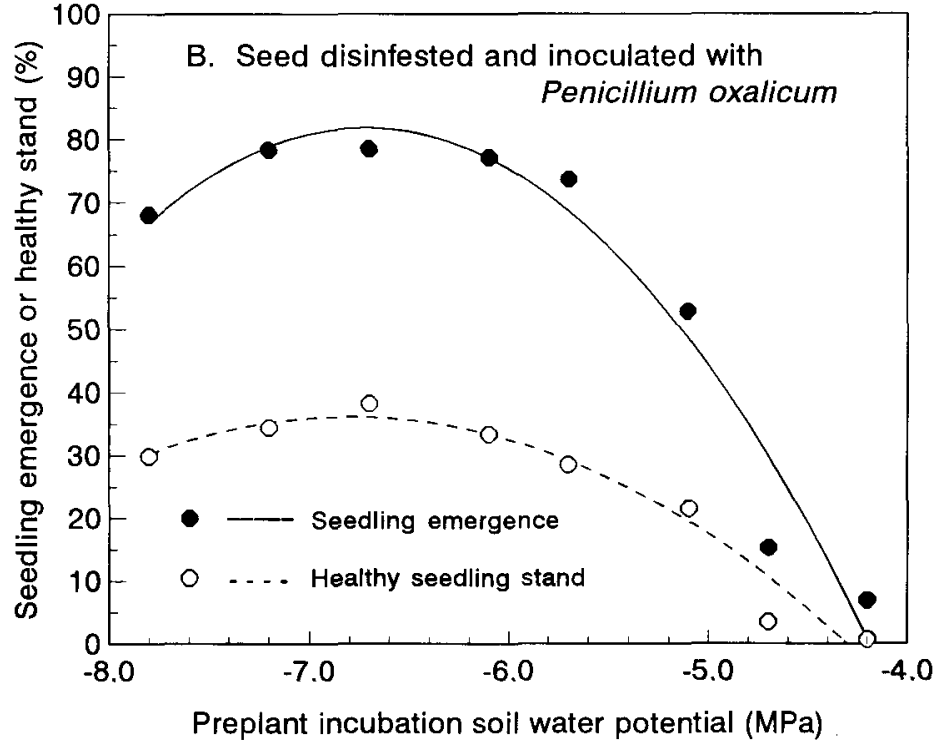

Preplant incubation soil water potential (MPa)

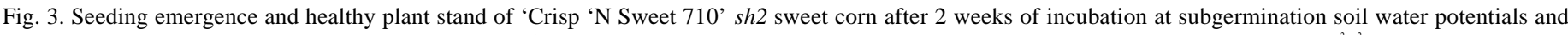
subsequent planting-and irrigation in-the greenhouse. (A) Seed disinfested with $0.4 \% \mathrm{NaOCl}$ only: $\mathrm{Y}($ emergence $)=27.24-16.61 \mathrm{X}-0.97 \mathrm{X}^{2}, \mathrm{r}^{2}=0.475^{* *} ; \mathrm{Y}(\mathrm{healthy}$ stand $)=-10.1-25.51 \mathrm{X}-1.62 \mathrm{X}^{2}, \mathrm{r} 2=0.560 * *$. (B) Seed disinfested and coated with $2 \times 10^{3}$ conidia of Penicillium oxalicum per seed: $\mathrm{Y}(\mathrm{emergence})=487.2-168.82 \mathrm{X}$ $-12.53 \mathrm{X}^{2}, r^{2}=0,871 * * ; \mathrm{Y}($ healthy stand $)=-227.8-77.32 \mathrm{X}-5,67 \mathrm{X}^{2}, r^{2}=0.722 * *$. 
Table 6. Supersweet Jubilee seedling emergence and height after seed disinfestation and fungicide treatments, Western Agricultural Research Center.'

\begin{tabular}{lccc}
\hline Seed treatment & $\begin{array}{c}\text { Seed treatment specifications } \\
\text { (rate/ timing) }\end{array}$ & $\begin{array}{c}\text { Emergence } \\
(\%)\end{array}$ & $\begin{array}{c}\mathrm{Ht} \\
(\mathrm{cm})^{y}\end{array}$ \\
\hline Nontreated & None & $39 \mathrm{a}^{*}$ & $10.1 \mathrm{a}$ \\
Surface-disinfested & $0.4 \% \mathrm{NaOCl}, 5 \mathrm{~min}$ & $48 \mathrm{ab}$ & $13.3 \mathrm{c}$ \\
Imazalil & $0.1 \mathrm{~g} \mathrm{a.i.} / \mathrm{kg}$ & $58 \mathrm{c}$ & $13.4 \mathrm{c}$ \\
Metalaxyl & $0.3 \mathrm{ga}$ a.i./kg & $52 \mathrm{bc}$ & $11.8 \mathrm{~b}$ \\
Imazalil plus metalaxyl & $0.1 / 0.3 \mathrm{~g} \mathrm{a.i.} / \mathrm{kg}$ & $74 \mathrm{~d}$ & $13.5 \mathrm{c}$
\end{tabular}

${ }^{2}$ Planted 29 July 1992. Seeds were planted into dry (-1.4 MPa) soil, with irrigation delayed 5 days. Soil temperatures during the 3 days after planting: ( $\max / \mathrm{min}) 33.3 /$ 25.0C. Pythium ultimum in soil :225 ppg.

'Seedling height 22 days after planting.

${ }^{\mathrm{x}}$ Mean separation within columns by protected LSD, $P=0.05$.

6). Surface disinfestation did not increase emergence significantly, but increased average seedling height 3 weeks after planting. Seed treatment with both metalaxyl and imazalil was necessary to achieve maximum seedling emergence, although metalaxyl alone increased seedling height to a lesser extent than did disinfestation or imazalil.

Many penicillin are adapted to moisture conditions too dry to support the growth of bacteria or of most other soil fungi, including P. ultimum (Cook and Duniway, 1981). Mislivec and Tuite (1970) reported that germination of conidia and sporulation of $P$. oxalicum occurred in the absence of free water at $86 \%$ relative humidity, which corresponds to a soil water potential of about $-20 \mathrm{MPa}$ (Papendick and Campbell, 1981). Wallace (1960) found wheat seeds that had decayed after planting in soil too dry to support germination were infected with species of Penicillium, Aspergillus, Rhizopus, and Mucor, with Penicillium spp. predominating. Mathre and Johnston (1991) described a dry seed decay of winter wheat, in which seeds planted in soil with inadequate moisture for seed germination were attacked by a species of Penicilium. The data presented here confirm the ability of $P$. oxalicum to cause injury to seeds under dry soil conditions,

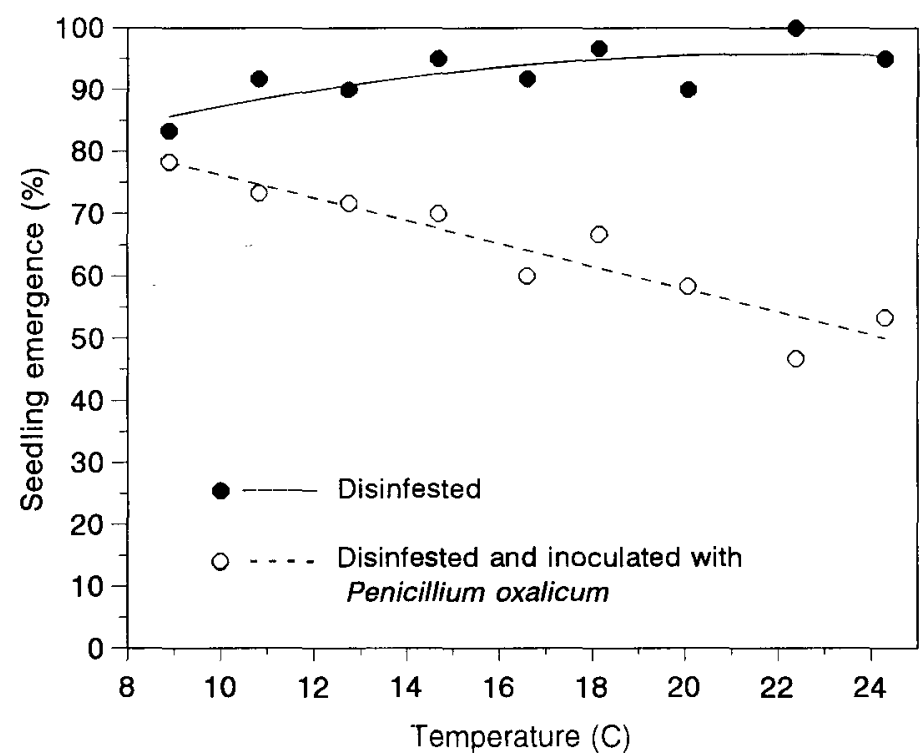

Fig. 4. Temperature effects on seedling emergence of 'Crisp N Sweet 710' sh2 sweet corn in pasteurized soil after disinfestation with $0.470 \mathrm{NaOCl}$ only or disinfestation and inoculation with $2 \times 10^{3}$ conidia of Penicillium oxalicum per seed, $\mathrm{Y}($ disinfected $)=67.32$ $+2.58 \mathrm{X}-0.06 \mathrm{X}^{2}, r^{2}=0.421^{* *} ; Y(P$. oxalicum $)=94.58-1.84 \mathrm{X}, r^{2}=0.530 * *$.

\section{Soil temperature}

Seedling emergence of disinfested 'Crisp 'N Sweet 710' in pasteurized soil was reduced at the lowest test temperature (Fig. 4), demonstrating the effects of imbibitional chilling injury on sweet corn seed (Cal and Obendorf, 1972). Mathre et al. (1994) also found that low temperatures reduced emergence of 'Crisp ' $N$ Sweet 710' sh2 sweet corn in sterile soil. Emergence from seed inoculated with $P$. oxalicum was lower than that from disinfested seed at all temperatures, but the difference between inoculated and noninoculated seed was progressively greater in warmer soil. Endosperm and pericarp remnants of seeds inoculated with $P$. oxalicum bore abundant (87\%-100\%) sporulation of Penicillium spp. at all temperatures, while sporulation on disinfested seed increased from none at $8.9 \mathrm{C}$ to $10 \%$ above $20 \mathrm{C}$. This pattern of disease incidence, which was similar in both experiments, is in agreement with Hoppe's (1953) description of P. oxalicum as a warm-soil pathogen, with the reported optimum in vitro temperature for P. oxalicum of 28C (Mislivec and Tuite, 1970), and with Johann's (1928) observation that seedling emergence was reduced more at 24 and $28 \mathrm{C}$ than at 16 and 20C. However, it conflicts with Halfon-Meiri and Solel's report (1990) that inoculation with $P$. oxalicum reduced seedling -emergence and induced mesocotyl necrosis to a greater extent at 15 and $20 \mathrm{C}$ than at 25 and $30 \mathrm{C}$.

Penicillium oxalicum is one of several seed- and soilborne fungi that can reduce seedling stands of $s h 2$ sweet corn. Soilborne $P$. ultimum and soil- and seedborne Fusarium spp. may also be involved, and several investigators have pointed out the value of multi-component seed treatments, including those involving priming (Baird et al, 1994; Wilson et al., 1993). Whether seedborne fungi in general, and $P$. oxalicum in particular, will influence seedling stand and vigor will depend on the degree of fungal infestation and infection, soil moisture and temperature, and the relative impact of soilborne pathogens such as $P$. ultimum. In contrast to $P$. ultimum, which causes the greatest degree of seed decay and seed decay under cold, wet soil conditions (Mathre et al., 1994), P. oxalicum is able to grow, sporulate, and cause seed decay and seedling blight in warmer and drier soils.

In arid areas of the west, this research has implications for irrigation management at the time of seeding. When adequate moisture for seed germination is available, soil temperatures above 20C favor seed germination and growth of the sweet corn seedling and reduce pythium seed decay (Mathre et al., 1994). Planting into soil in which moisture is inadequate for rapid germination may increase the impact of seedborne fungi such as $P$. oxalicum, particularly if irrigation is delayed. In addition to chemical or biological seed treatment, soil temperature monitoring and adjustment of soil moisture through time] y preplant irrigation should aid western growers of $s h 2$ sweet corn in stand establishment. In many other $\operatorname{sh} 2$ sweet corn growing areas of the United States, growers have less control over soil moisture. Here. the results of this research reinforce the importance of broad-spectrum, multi-component seed treatments that would guard against the major fungal pathogens involved in sh2 sweet corn stand failure

\section{Literature Cited}

Ali-Shtayeh, M. S., C.L. Lim-Ho, and M.W. Dick. 1986. An improved method and medium for quantitative estimates of populations of Pythium species from soil. Trans. Br. Mycol. Soc. 86-3947.

Anderegg, J. and Guthrie, J.W. 1981, SeedborneFusarium moniliforme and seedling infection in hybrid sweet corn. Phytopathology 71:11961198.

Baird, R. E., C. Nankam, P. Fallah Moghaddam,, and J.K. Pataky. 1994. Evaluation of seed treatments on shrunken-2 sweet corn. Plant Dis. 78:817-821. 
Bacon, C. W., D.M. Hinton, and M.D. Richardson. 1994. A corn seedling assay for resistance to Fusarium monilifonne. Plant Dis. 78:302-305.

Cal, J.P. and R.L. Obendorf. 1972. Imbibitional chilling injury in Zea mays $L$. altered by initial kernel moisture and maternal parent. Crop Sci. 12:369-373.

Caldwell, R. W., J. Tuite, and W.W. Carlton. 1981. Pathogenicity of Penicillin to corn ears. Phytopathology71:175-180.

Callan, N.W., D.E. Mathre, and J.B. Miller. 1990. Bio-priming seed treatment for biological control of Pythium ultimum preemergence damping-off in sh2 sweet corn. Plant Dis. 74:368-372.

Callan, N. W., D.E. Mathre, and J.B. Miller. 1991. Field performance of sweet corn seed bio-primed and coated with Pseudomonas fluorescens AB254. HortScience 26:1163-1165.

Chuang, T.Y. and W.H. Ko. 1981. Propagule size: Its relation to population density of microorganisms in soil. Soil Biol. Biochem. 13: 185-1 90.

Cook, R.J. and L.M. Duniway. 1981. Water potential relations in the life cycle of soilborne plant pathogens, p. 119-139. In: J. F. Parr, R. I. Papendick, and R.E. Wildung (eds.). Water potential relations in soil microbiology. Soil Sci. Soc. Amer., Madison, Wis.

Halfon-Meiri, A. and Z. Solel. 1989. Control of seed-borne Penicillium oxalicum in sweet corn by seed treatment. Z. PflKrh.PflSch. 96:636639.

Halfon-Meiri, A. and Z. Solel. 1990. Factors affecting seedling blight of sweet corn caused by seedborne Penicillium oxalicum. Plant Dis. 74:36 39.

Hoppe, P.E. 1953. Infections of corn seedlings, p. 377-380. In: U.S. Dept. Agr. Yearbook of Agriculture.

Johann, H. 1928. Penicillium injury to corn seedlings. Phytopathology 18:239-242.

Johann, H., J.R. Holbert, and J.G. Dickson. 1931. Further studies of Penicillium injury to corn. J. Agr. Res. 43:757-790.

Johnston, R.H. and D.E. Mathre. 1993. Seed treatment for control of Fusarium root rot of spring wheat, 1992. Fungicide and Nematicide Tests 48:323.

Koehler, B. 1942. Natural mode of entrance of fungi into corn ears. J. Agr. Res. 64:421-442.

Kommedahl, T. and C.E. Windels. 1981. Root-, stalk-, and ear-infecting Fusarium species on corn in the U. S., p. 94-103. In: P.E. Nelson, T.A. Tousson, and R.J. Cook (eds.). Fusarium: Diseases, biology, and taxonomy. The Pennsylvania State Univ. Press, University Park, Pa.

Kommedahl, T. and C.E. Windels. 1986. Treatment of maize seeds, $p$. 163-1 83. In: K.A. Jeffs (ed.). Seed Treatment. BCPC Publications,
Thornton Heath, Surrey.

Lund, R.E. 1994. MSUSTAT. Res. and Dev. Inst., Montana State Univ.

Mathre, D.E. and R.H. Johnston. 1991. Control of dry seed decay of wheat Plant Dis. 75:957-959.

Mathre, D. E., N.W. Callan, R. H. Johnston, J. B. Miller, and A. Schwend. 1994. Factors influencing the control of Pythium ultimum-induced seed decay by seed treatment with Pseudomonas aureofaciens AB254. Crop Protection 13:301-307.

Mislivec, P.B. and J. Tuite. 1970. Temperature and relative humidity requirements of species of Penicillium isolated from yellow dent corn kernels. Mycologia 62:75-88.

Mohan, S.K. and D.O. Wilson. 1990. Fungi associated with seed and seedling blight of sh-2 sweet corn in Idaho. Phytopathology 80:891. (Abstr.)

Papendick, R.I. and G.S. Campbell. 1981. Theory and measurement of water potential, p. 1-22. In: J. F. Parr, R. I. Papendick, and R. E. Wildung. Water potential relations in soil microbiology. Soil Sci. Soc Amer., Madison, Wis.

Parera, C.A. and D.J. Cantliffe. 1991. Improved germination and modified imbibition of shrunken-2 sweet corn by seed disinfestation and solid matrix priming. J. Amer. Soc. Hort Sci. 116:942-945.

Parera, C. A., and D.J. Cantliffe. 1992. Enhanced emergence and seedling vigor in shrunken-2 sweet corn via seed disinfestation and solid matrix priming. J. Amer. Soc. Hort. Sci. 117:400-403.

Parera, C.A. and D.J. Cantliffe. 1994. Presowing seed treatments to enhance supersweet sweet corn seed and seedling quality. HortScience 29:277-278.

Raper, K.B. and C. Thorn. 1949. A manual of the Penicillin. Williams and Wilkins Co., Baltimore.

Schroeder, D.B. 1965. Seedling blight, stalk rot and ear rot of sweet corn caused by Penicillium oxalicum. PhD thesis, Univ. of Minnesota.

Styer, R.C. and D.J. Cantliffe. 1984. Infection of two mutants of sweet corn by Fusarium moniliforme and its effect on seedling vigor. Phytopathology 74:189-194.

Wallace, H.A.H. 1960. Factors affecting subsequent germination of seeds sown in soils of subgermination moisture content. Can. J. Botany 38:287-306.

Wilson, D. O., S.K. Mohan, E.A. Knott, and B. Shafii. 1993. Evaluation of fungicide seed treatments for shrunken-2 ("supersweet") sweet corn. Plant Dis. 77:348-351.

Wilson, D.O. Jr. and S.K. Mohan. 1991. Seedling blight of sweet corn. Idaho Agr. Expt. Sta. Cum. Info. Ser. 879. 